\title{
Biowaste compost effects on productive and qualitative characteristics of some field crops and on soil fertility
}

\author{
Giovanni Fecondo, Sabina Bucciarelli, Elvio Di Paolo, Giovanni Ghianni \\ Centro per la Sperimentazione e Divulgazione delle Tecniche Irrigue, Vasto (CH), Italy
}

\begin{abstract}
Biowaste compost exploitation is a way of recovering agricultural soil fertility that in these last decades decreased up to a desertification limit. In order to test compost efficacy on crop yield and soil fertility, in the period 2011-2013 at COTIR experimental farm, a trial comparing different amounts of compost on two crop rotations was carried out. Crop rotations tested were durum wheat-sunflower-durum wheat and tomato-durum wheat-pepper. Results showed that the use of $40 \mathrm{tha}^{-1}$ of compost increased wheat grain yield and protein content if compared to control and mineral fertilised treatment. Compost application at $40 \mathrm{t} \mathrm{ha}^{-1}$ increased also yield of pepper in the first two harvest times, while during the third harvest, which included green and red berries, (the) yield was statistically different only if compared to control treatment. Moreover, compost improved soil fertility both in terms of organic matter and main nutritional elements, while a negative aspect of its use was the increase of soil electric conductivity, although no negative effect on crops yield were observed.
\end{abstract}

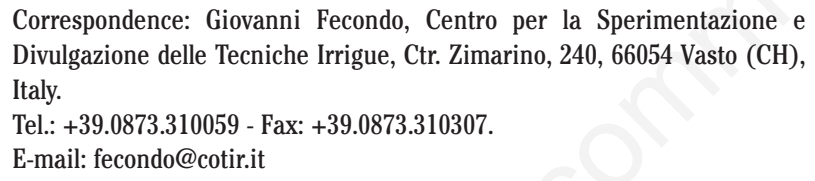

Key words: Biowaste compost; soil fertility; wheat proteins; sunflower; tomato; pepper.

Acknowledgements: the authors would like to acknowledge Donato Civitella, Mario D'Ercole, Giovanni Rizzo, Francesco Ventura, Armando Mammarella and Laura De Francesco for their support in field and laboratory. Moreover the author thanks for making available compost to CIVETA and SOGESA compost plants (C.da Valle Cena, Cupello - CH and C.da Grasciano, Notaresco - TE). Research made with Abruzzo region grant.

Conference presentation: SIA XLIII Congress, Pisa, 2014.

Received for publication: 18 November 2014.

Revision received: 23 January 2015.

Accepted for publication: 28 January 2015.

(C) Copyright G. Fecondo et al., 2015

Licensee PAGEPress, Italy

Italian Journal of Agronomy 2015; 10:628

doi:10.4081/ija.2015.628

This article is distributed under the terms of the Creative Commons Attribution Noncommercial License (by-nc 3.0) which permits any noncommercial use, distribution, and reproduction in any medium, provided the original author(s) and source are credited.

\section{Introduction}

In the last decades industrialisation and urbanisation processes in the Western countries were quite intense. These processes, on one hand increased population wealth, on the other created serious problems concerning the management of disposal and wastewater from civil and industrial plants (Italian Regulation, 1982). Within year 2020 at least $50 \%$ of urban wastes will have to be recovered, in particular organic waste (Italian Regulation, 2006a; European Commission, 2008). The European Commission with COM 13 (2011) reports to the parliament the necessity to adopt a waste management strategy, in order to reduce considerably waste production and, at the same time, to increase recycling and composting.

Contextually intensive agriculture leads to a simplification of cropping system with consequent reduction of soil organic matter. In Central and Southern Italy crop systems based on continuous durum wheat were used in order to increase productivity. This cropping system, based on chemical fertilisation and stubble burning, decreased considerably soil organic matter. Studies concerning the Italian soils showed that over $50 \%$ of agricultural soils have low organic matter, and this percentage reaches 64\% for Abruzzo region (Cappelli e Aureli, 1998). EU Climate Change Programme (ECCP, 2001) soil strategy pays a growing attention to the role of organic matter in soils, in order to ensure soil fertility, biodiversity and to prevent desertification.

The use of compost in agriculture is a way to improve soil organic matter, to guarantee a positive humic balance and to allow for fertility recovery (Fecondo et al., 2008). On this basis, at COTIR experimental farm in the years 2011-2013, an experimentation based on application of biowaste compost on field crops was carried out with the aim to test the effect of biowaste compost distribution on durum wheat, sunflowers, tomato and pepper arranged in two crop rotations: wheat-sunflower-wheat (WSW) and tomato-wheat-pepper (TWP) which are the main crop rotations adopted, respectively, in rainfeed and irrigated areas of Abruzzo region.

\section{Materials and methods}

\section{Experimental design and crop management}

Field experiments were carried out in Vasto (Chieti, Italy) ( $42^{\circ} 10^{\prime \prime}$ lat. N; $14^{\circ} 38^{\prime}$ long. E, $30 \mathrm{~m}$ asl) in the growing seasons 2010/2011, 2011/2012 and 2012/2013 at the experimental farm of the CO.T.IR. Centre for Irrigation Techniques.

The soil is a vertisol of alluvial origin (Aquic Haploxerert), silty-clayloam with the following average characteristics in the $0-40 \mathrm{~cm}$ depth: clay $37.7 \%$, silt $56.7 \%$, sand $5.6 \%$, pH (water) 8.0 , total nitrogen $1.4 \mathrm{~g}$ $\mathrm{kg}^{-1}$, organic matter $2.0 \%, \mathrm{NaHCO}_{3}$-extractable phosphorus (P) 12.0 $\mathrm{mg} \mathrm{kg}{ }^{-1}, \mathrm{NH}_{4} \mathrm{O}$ Ac-extractable $\mathrm{K}_{2} \mathrm{O}, 380 \mathrm{mg} \mathrm{kg}^{-1}$, bulk density $1.21 \mathrm{~kg}$ 
$\mathrm{dm}^{-3}$, field capacity (Richard's plate, $-0.03 \mathrm{MPa}$ ) water content $0.40 \mathrm{~m}^{3}$ $\mathrm{m}^{-3}$; permanent wilting point $(-1.5 \mathrm{MPa})$ water content $0.22 \mathrm{~m}^{3} \mathrm{~m}^{-3}$, available soil water $180 \mathrm{~mm} \mathrm{~m}^{-1}$. The climate is attenuate thermomediterranean (FAO-UNESCO, 1963) with minimum temperatures below $0^{\circ} \mathrm{C}$ in the winter and about $34-36^{\circ} \mathrm{C}$, as maximum temperatures, in the summer. Annual rainfall (mean $650 \mathrm{~mm}$, considering 40-year long term period) is mostly concentrated during the autumn and spring months and class A pan evaporation fluctuates, during July and August, between 6 and $8 \mathrm{~mm} \mathrm{~d}^{-1}$ in clear sky days. The effect of biowaste compost was tested on durum wheat, sunflowers, tomato and pepper arranged in two crop rotations: WSW and TWP. The varieties used were Ignazio for durum wheat, Pavia for tomato, Rumbasol for sunflower and Altino sweet pepper (a local variety of red pepper). As experimental design a randomised block with three replications was used with elementary plots of $40 \mathrm{~m}^{2}$. For each rotation four treatments were compared: control (C) without any fertilisation, mineral fertilised (MF), $\mathrm{C} 20$ and $\mathrm{C} 40$, respectively 20 and $40 \mathrm{tha}^{-1}$ of biowaste compost.

Compost was distributed only during the first two years of experimentation before soil plowing. Certified biowaste compost used had chemical, physical and biological characteristics in agreement with the Decree of Law n. 217/2006 (Italian Regulation, 2006b). The main chemical characteristics, expressed on dry matter basis, were: dry matter $77.8 \%$, humic acids $8.9 \%$, organic carbon (C) $35.1 \%$, total nitrogen (N) $2.1 \%$ of which $95 \%$ was organic form, total P $1.1 \%$, total potassium (K) $5 \%$ and $\mathrm{C} / \mathrm{N} 13.5$.

Plots of all treatments were moldboard plowed to $30 \mathrm{~cm}$ depth followed by secondary tillage with a soil grubber and harrow for seedbed and soil transplanting preparation. Dates of main agronomic practices are reported in Table 1. Wheat and sunflower were sowing at a rate of 400 and 8 germinable seeds per $\mathrm{m}^{2}$, while tomato and pepper were transplanted with a plant population of 3.3 plants per $\mathrm{m}^{2}$. Weeds were controlled by mechanical weeding in tomato, sunflower and pepper and by herbicide application in wheat $\left(0.01 \mathrm{~kg} \mathrm{ha}^{-1}\right.$ tribenuron-metile and $0.45 \mathrm{~kg} \mathrm{ha}^{-1}$ cloquintocet-mexyl, pinoxaden). Tomato and pepper were irrigated with drip line with emitters of $0.4 \mathrm{~L} \mathrm{~h}^{-1}$ flow, $0.3 \mathrm{~m}$ apart, distributing 200 and $140 \mathrm{~mm}$ water respectively for tomato and pepper. Specific fungicides and insecticides were used on tomato and pepper to control the main pests (douny mildew, oidium, aphid and acari).

Pre-sowing mineral fertiliser was applied only in the treatment MF with $36 \mathrm{~kg} \mathrm{ha}^{-1}$ of $\mathrm{N}$ and $92 \mathrm{~kg} \mathrm{ha}^{-1}$ of $\mathrm{P}$, as ammonium phosphate, for durum wheat and sunflower, $25 \mathrm{~kg} \mathrm{ha}^{-1}$ of $\mathrm{N}, 45 \mathrm{~kg} \mathrm{ha}^{-1}$ of $\mathrm{P}$ and $40 \mathrm{~kg}$ $\mathrm{ha}^{-1}$ of $\mathrm{K}$ for tomato and $36 \mathrm{~kg} \mathrm{ha}^{-1}$ of $\mathrm{N}, 36 \mathrm{~kg} \mathrm{ha}^{-1}$ of $\mathrm{P}$ and $72 \mathrm{~kg} \mathrm{ha}^{-1}$ $\mathrm{K}$ for pepper. Top-dress $\mathrm{N}$ in the MF treatment was applied as ammonium nitrate at a rate of $104 \mathrm{~kg} \mathrm{ha}^{-1} \mathrm{~N}$ for wheat and $78 \mathrm{~kg} \mathrm{ha}^{-1} \mathrm{~N}$ for tomato and sunflower.

Treatments $\mathrm{C} 20$ and $\mathrm{C} 40$ were top-dress fertilised with ammonium nitrate, on the basis of a $\mathrm{N}$ balance, taking into account compost mineral $\mathrm{N}$ content and mineralisation rate of compost organic N. Organic $\mathrm{N}$ mineralisation rate was fixed at $10 \%$ on annual basis (Agritrasfer-InSud, 2012) and the amount of available $\mathrm{N}$ for crops was estimated multiplying the amount of mineralised $N$ per $8 / 12$ and 5/12, respectively, for wheat and summer crops. The doses of top dress $\mathrm{N}$ for each crop were calculated with respect to the total $\mathrm{N}$ applied to MF treatments considering negligible $\mathrm{N}$ losses. In the first year wheat (rotation WSW) was top dressed with 92 and $45 \mathrm{~kg} \mathrm{ha}^{-1} \mathrm{~N}$, respectively for treatment C20 and $\mathrm{C} 40$, while tomato (rotation TWP) was fertilised with 66 for and 29 $\mathrm{kg} \mathrm{ha}^{-1} \mathrm{~N}$. In the second and third year only C20 treatments were top dressed, respectively sunflower with $48 \mathrm{~kg} \mathrm{ha}^{-1} \mathrm{~N}$, tomato with $45 \mathrm{~kg}$ $\mathrm{ha}^{-1} \mathrm{~N}$, wheat with $50 \mathrm{~kg} \mathrm{ha}^{-1} \mathrm{~N}$ and pepper with $60 \mathrm{~kg} \mathrm{ha}^{-1} \mathrm{~N}$.

\section{Data collection and data processing}

At harvest, on durum wheat and sunflower, were determined yield, test weight, thousand-kernel weight, protein content (Kjeldahl N x 6.25 ) and oil content (Soxhlet extraction) were measured respectively for wheat and sunflower. On tomato and pepper were determined marketable yield, green berries, deteriorated yield, optic residue, acidity and $\mathrm{pH}$ (in water).

At the end of three years of experimentation, soil samples were taken at 0-0.2 and 0.21-0.4 m depth. Soil samples were oven dry at $65^{\circ} \mathrm{C}$

Table 1. Crop management practices adopted during the experiment.

\begin{tabular}{lccc} 
Cropping rotation WSW & Wheat & Sunflower & Wheat \\
Pre-sowing fertilisation & $2 / 12 / 10$ & $28 / 3 / 12$ & $6 / 11 / 12$ \\
Sowing & $6 / 12 / 10$ & $12 / 04 / 12$ & $6 / 11 / 12$ \\
\hline Top-dress fertilisation & $9 / 2 / 11$ & $22 / 5 / 12$ & $18 / 4 / 13$ \\
Weed control & $8 / 4 / 11$ & $22 / 5 / 12$ & $22 / 3 / 12$ \\
\hline Cropping rotation TWP & Tomato & Wheat & Pepper \\
Pre-sowing fertilisation & $19 / 4 / 11$ & $2 / 12 / 11$ & $17 / 5 / 13$ \\
Sowing & - & $4 / 12 / 11$ & - \\
\hline Transplantation & $5 / 5 / 11$ & - & $16 / 5 / 13$ \\
Top-dress fertilisation & $24 / 5 / 11$ & $13 / 3 / 12$ & $24 / 06 / 13$ \\
\hline Irrigation N & 10 & - & 7 \\
Weed control & $30 / 5-22 / 6 / 11$ & $22 / 3 / 12$ & $24 / 6-20 / 7 / 13$ \\
\hline Pest control & $19-24 / 5-13 / 6-4-20-29 / 07 / 11$ & - & $15 / 6-2-23 / 7 / 13$ \\
\hline
\end{tabular}

WSW, wheat-sunflower-durum wheat; TWP, tomato-durum wheat-pepper; N, nitrogen.

Table 2. Crop yield obtained in the growing season 2010/2011, 2011/2012 and 2012/2013 for the two crop rotations, expressed in $t$ ha ${ }^{-1}$.

\begin{tabular}{|c|c|c|c|c|c|c|}
\hline \multirow[t]{2}{*}{ Treatments } & \multicolumn{3}{|c|}{ Crop rotation WSW } & \multicolumn{3}{|c|}{ Crop rotation TWP } \\
\hline & $\begin{array}{l}\text { Wheat } \\
2010 / 2011\end{array}$ & $\begin{array}{l}\text { Sunflower } \\
2011 / 2012\end{array}$ & $\begin{array}{c}\text { Wheat } \\
2012 / 2013\end{array}$ & $\begin{array}{l}\text { Tomato } \\
2010 / 2011\end{array}$ & $\begin{array}{c}\text { Wheat } \\
2011 / 2012\end{array}$ & $\begin{array}{l}\text { Pepper } \\
2012 / 2013\end{array}$ \\
\hline $\mathrm{C}$ & $3.5^{\mathrm{b}}$ & 1.3 & $3.8^{b}$ & 73.2 & $5.3^{\mathrm{b}}$ & $7.8^{\mathrm{b}}$ \\
\hline MF & $4.2^{\mathrm{b}}$ & 1.3 & $5.5^{\mathrm{a}}$ & 76.5 & $6.3^{\mathrm{ab}}$ & $10.4^{\mathrm{a}}$ \\
\hline $\mathrm{C} 20$ & $4.7^{\mathrm{b}}$ & 1.3 & $5.1^{\mathrm{a}}$ & 77.9 & $6.5^{\mathrm{a}}$ & $10.1^{\mathrm{a}}$ \\
\hline $\mathrm{C} 40$ & $5.9^{\mathrm{a}}$ & 1.2 & $4.7^{\mathrm{ab}}$ & 81.4 & $7^{\mathrm{a}}$ & $11.2^{\mathrm{a}}$ \\
\hline F-ANOVA & $*$ & n.s. & $*$ & n.s. & $*$ & $*$ \\
\hline CV (\%) & 14.1 & 38.5 & 12.5 & 15.1 & 8.7 & 10.3 \\
\hline
\end{tabular}

WSW, wheat-sunflower-durum wheat; TWP, tomato-durum wheat-pepper; C, control without any fertilisation; MF, mineral fertilised; C20, C40, 20 and $40 \mathrm{t}$ ha ${ }^{-1}$ of biowaste compost, respectively; n.s., not significant. *Significant at $\mathrm{P} \leq 0.05$. a,bValues followed by different letters are significantly different according to Duncan's test. 
for $24 \mathrm{~h}$, finely ground by a specific mill and analysed in order to determine $\mathrm{pH}$ and conductivity (soil/water ratio 1:2), organic matter (Walkley-Black organic carbon multiplied by 0.172$)$, total N (Kjeldahl), available P (Olsen), extractable K (ammonium acetate extraction). Experimental data were analysed using ANOVA and Duncan's test for means separation (Statistica, StatSoft Inc., Tulsa, OK, USA).

\section{Results and discussion}

\section{Crop parameters}

Table 2 reports crops yield of the two rotations. Treatment $\mathrm{C} 40$ has significantly increased yield of wheat in the WSW rotation during the first growing season, while in the third one yield was not significantly different from other treatments and the highest value was achieved by MF treatment. In the third year high percentage of plant lodging occurred in treatments C40 (57\%) and C20 (53\%), we suppose as a consequence of higher $\mathrm{N}$ availability.

Compost increased also wheat quality, number of spike yield per $\mathrm{m}^{2}$ and reduced the Fusarium incidence (Table 2).

Treatment C40 has significantly increased protein content of $26 \%$ and $14 \%$ in comparison to the $\mathrm{C}$ and $\mathrm{MF}$ treatments respectively. It has increased number of spike per $\mathrm{m}^{2}$ over $52 \%$ in comparison to the control and reduced the incidence of Fusarium of $84 \%$ and $69 \%$ in respect to $\mathrm{C}$ and MF treatments (Table 3 ). Whereas sunflower yield was not affected by experimental treatments. Correct interpretation of the results on sunflower was not possible in consequence of the high coef- ficient of variation (38.5\%) owed to the plants damaging by wild animals (wild boar). Treatment C40 has slightly improved seed quality in terms of test weight ( $48.4 \mathrm{~kg} \mathrm{hL}^{-1}$ vs $45.2 \mathrm{~kg} \mathrm{hL}^{-1}$ ) and thousand-kernel weight ( $47.2 \mathrm{~g} v s 46.8 \mathrm{~g}$ ) if compared to the $\mathrm{C}$. No statistical differences were observed for the seed oil percentage content.

In the crop rotation TWP, treatment C40 increased wheat yield only if compared to the control, no differences occurred in comparison to MF and C20 treatments (Table 2), but it has significantly increased protein content and reduced Fusarium incidence (Table 3).

Tomato yield was not significantly affected by treatments although marketable yield of $\mathrm{C} 40$ treatment was the highest (Table 1). In Figure 1, component of yield are showed the in terms of marketable, green and decayed barriers.

In pepper treatment $\mathrm{C} 40$ increased marketable yield (red barriers) during the first two harvests as compared to $\mathrm{C}$ and MF treatments (Figure 2), whereas in the third harvest (sum of red and green berries) no differences were observed. Total yield (sum of all harvest) of C20 and $\mathrm{C} 40$ did not differ from MF, but only in comparison to the control (Table 2). Dry matter content of pepper barriers was not affected by the treatments, but increased during the season from the first to the third harvest (12.9\%, 17.9 and 22.4\%). Compost did not affect significantly acidity, $\mathrm{pH}$ and optical residue of pepper and tomato.

\section{Pedologic surveys}

Data reported in Table 4 show that compost affected significantly all soil parameters, except $\mathrm{pH}$, as observed by Eghball et al. (2004). No differences were observed between rotations and soil samples taken at 0 0.2 and $0.21-0.40 \mathrm{~m}$ depth. The homogeneity between soil depths is

Table 3. Qualitative characteristics, spike yield and Fusarium incidence (number plants infected per $\mathrm{m}^{2}$ ) of wheat crop in the two rotations.

\begin{tabular}{|c|c|c|c|c|c|}
\hline Treatment & $\begin{array}{l}\text { Test weight } \\
\left(\mathrm{kg} \mathrm{hL^{-1 }}\right)\end{array}$ & $\begin{array}{l}\text { Thousand kernel weight } \\
\text { (g) }\end{array}$ & $\begin{array}{l}\text { Protein content } \\
\text { (\% s.s.) }\end{array}$ & $\begin{array}{c}\text { Spike yield } \\
\text { (n. spikes } \mathrm{m}^{-2} \text { ) }\end{array}$ & $\begin{array}{c}\text { Fusarium } \\
\text { (n. plants } \mathrm{m}^{-2} \text { ) }\end{array}$ \\
\hline \multicolumn{6}{|c|}{ Growing season 2010-2011 - rotation WSW } \\
\hline $\mathrm{C}$ & 78.7 & 47.3 & $13.1^{\mathrm{c}}$ & $228^{b}$ & $119^{a}$ \\
\hline MF & 78.4 & 48.5 & $14.2^{\mathrm{bc}}$ & $331^{\mathrm{a}}$ & $69^{\mathrm{b}}$ \\
\hline $\mathrm{C} 20$ & 79.4 & 47.3 & $15^{\mathrm{ab}}$ & $345^{\mathrm{a}}$ & $2^{c}$ \\
\hline $\mathrm{C} 40$ & 80.2 & 52.5 & $15.8^{\mathrm{a}}$ & $387^{\mathrm{a}}$ & $11^{\mathrm{c}}$ \\
\hline F-ANOVA & n.s. & n.s. & $*$ & $*$ & $* *$ \\
\hline CV $(\%)$ & 1.8 & 5.9 & 12.7 & 13.8 & 16.3 \\
\hline \multicolumn{6}{|c|}{ Growing season 2011-2012 - rotation TWP } \\
\hline $\mathrm{C}$ & $75.3^{c}$ & $47^{\mathrm{b}}$ & $14.2^{\mathrm{b}}$ & 400 & $22^{\mathrm{a}}$ \\
\hline MF & $77.5^{\mathrm{b}}$ & $47.1^{\mathrm{b}}$ & $14.8^{\mathrm{ab}}$ & 381 & $14^{\mathrm{ab}}$ \\
\hline $\mathrm{C} 20$ & $78.8^{b}$ & $47.5^{b}$ & $15^{\mathrm{ab}}$ & 413 & $15^{\mathrm{ab}}$ \\
\hline $\mathrm{C} 40$ & $82.7^{\mathrm{a}}$ & $48.3^{\mathrm{a}}$ & $17.1^{\mathrm{a}}$ & 472 & $7^{\mathrm{b}}$ \\
\hline F-ANOVA & $* *$ & $*$ & $*$ & n.s. & $*$ \\
\hline CV (\%) & 1.5 & 0.8 & 6.2 & 11.6 & 33.1 \\
\hline \multicolumn{6}{|c|}{ Growing season 2012-2013 - rotation WSW } \\
\hline $\mathrm{C}$ & 75.8 & 49 & $12.1^{\mathrm{b}}$ & $322^{\mathrm{d}}$ & $87^{\mathrm{a}}$ \\
\hline $\mathrm{MF}$ & 75.6 & 50.1 & $13.8^{\mathrm{ab}}$ & $350^{c}$ & $36^{\mathrm{b}}$ \\
\hline $\mathrm{C} 20$ & 76 & 49.4 & $14^{\mathrm{ab}}$ & $389^{b}$ & $19 c$ \\
\hline $\mathrm{C} 40$ & 77 & 47.3 & $16^{\mathrm{a}}$ & $450^{\mathrm{a}}$ & $22^{c}$ \\
\hline F-ANOVA & n.s. & n.s. & $*$ & $* *$ & $* *$ \\
\hline CV (\%) & 4.5 & 8.6 & 8.6 & 4.2 & 5.5 \\
\hline
\end{tabular}

WSW, wheat-sunflower-durum wheat; TWP, tomato-durum wheat-pepper; C, control without any fertilisation; MF, mineral fertilised; C20, C40, 20 and 40 t ha ${ }^{-1}$ of biowaste compost, respectively; n.s., not significant difference. *Significant at $\mathrm{P} \leq 0.05$; ${ }^{* *}$ significant at $\mathrm{P} \leq 0.01$. a-dValues followed by different letters are significantly different according to Duncan's test. 
probably dewed to tillage operation that determined a uniform distribution of the compost along soil profile. Organic matter content, which represents one of the most important markers of soil fertility, reached $3 \%$ in C40 in comparison to $2 \%$ of control, which was not significantly different from MF and $\mathrm{C} 20$. With regard to the main plant nutrients, C40 increased total $\mathrm{N}$ of $21 \%$ ( $1.7 \mathrm{~g} \mathrm{~kg}^{-1}$ vs $1.4 \mathrm{~g} \mathrm{~kg}^{-1}$ of MF) and of $38 \%$ in comparison to $\mathrm{MF}$ and $\mathrm{C}$ treatments respectively. Treatment $\mathrm{C} 40$ increased available $\mathrm{P}$ of $46.6 \%$ (17.6 mg kg-1 vs $12 \mathrm{mg} \mathrm{kg}^{-1}$ ) and $\mathrm{K}$ of $18 \%$ (451 mg kg-1 vs $380 \mathrm{mg} \mathrm{kg}^{-1}$ ) in comparison to MF treatment. Similar results were observed by Casado-Vela et al. (2007). Electric conductivity increased significantly in both depths (Table 3) compared to MF treatment, with an average increment of 0.20 and $0.13 \mathrm{dS} \mathrm{m}^{-1}$ respectively for $\mathrm{C} 40$ and $\mathrm{C} 20$. In this experiment, soil salinity did not affect the performance and productivity of crops.

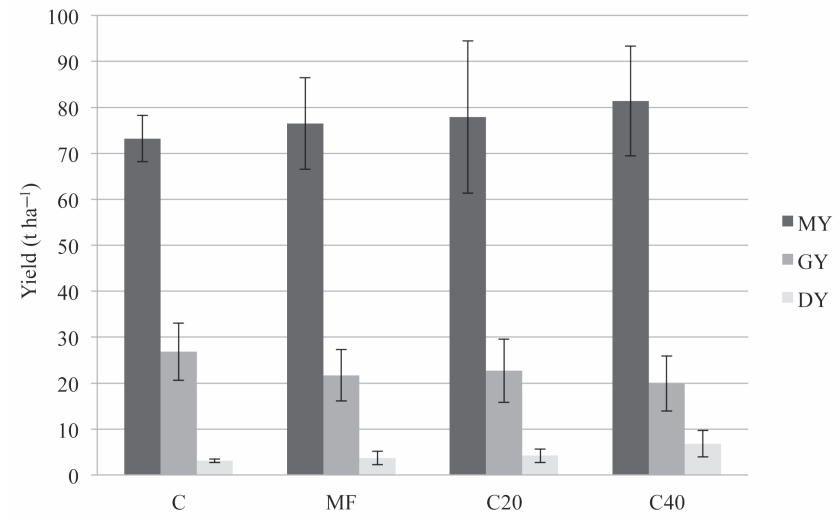

Figure 1. Marketable yield (MY), green berries (GY) and decayed berries (DY) of tomato under compost and mineral fertilisation in comparison to the control not fertilised. C, control without any fertilisation; MF, mineral fertilised; C20, C40, 20 and $40 \mathrm{t}$ $\mathrm{ha}^{-1}$ of biowaste compost, respectively.

\section{Conclusions}

Biowaste compost generally improved, in the examined crops, productive and qualitative characteristics both for wheat and sunflower, increased test weight, thousand kernel weight and protein content. Moreover reduced the incidence of important diseases such as Fusarium on wheat.

In particular, the use of compost at $40 \mathrm{tha}^{-1}$ allowed to reduce mineral fertilisers use without consequence for the crop as demonstrated by durum wheat grain yield and protein content, both increased by compost.

In wheat crop, plants lodging risk increased with compost application

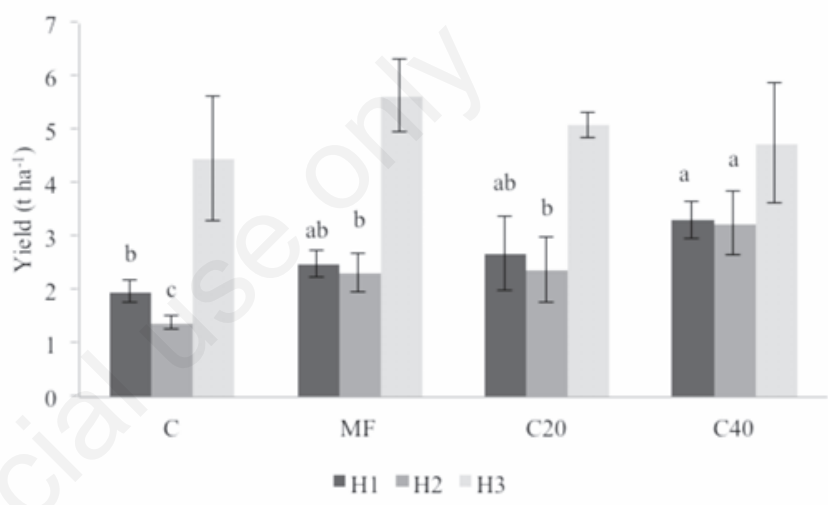

Figure 2. Yield of sweet pepper, under compost and mineral fertilisation in comparison to the control not fertilised, achieved during different harvest time (6 August - H1, 22 August - $\mathrm{H} 2$ and 6 September - H3). C, control without any fertilisation; MF, mineral fertilised; C20, C40, 20 and $40 \mathrm{t} \mathrm{ha}^{-1}$ of biowaste compost, respectively.

Table 4. Main soil chemical characteristics of the experimental plots at the end of third year experiment.

\begin{tabular}{|c|c|c|c|c|c|c|}
\hline Treatments & $\mathrm{pH}$ & $\begin{array}{c}\text { E.C. } \\
\left(\mathrm{dS} \mathrm{m}^{-1}\right)\end{array}$ & $\begin{array}{c}\text { Organic matter } \\
(\%)\end{array}$ & $\begin{array}{l}\text { Total N } \\
\left(\mathrm{g} \mathrm{kg}^{-1}\right)\end{array}$ & $\begin{array}{l}\text { Available P } \\
\left(\mathrm{mg} \mathrm{kg}^{-1}\right)\end{array}$ & $\begin{array}{c}\text { Extractable K } \\
\left(\mathrm{mg} \mathrm{kg}^{-1}\right)\end{array}$ \\
\hline \multicolumn{7}{|c|}{ Depth 0-20 cm } \\
\hline $\mathrm{C}$ & 7.9 & $0.24^{c}$ & $2.1^{\mathrm{b}}$ & $1.3^{\mathrm{b}}$ & $9.8^{b}$ & $373^{b}$ \\
\hline MF & 7.9 & $0.34^{\mathrm{bc}}$ & $2.2^{\mathrm{b}}$ & $1.4^{\mathrm{ab}}$ & $12.4^{\mathrm{ab}}$ & $395.2^{b}$ \\
\hline $\mathrm{C} 20$ & 7.7 & $0.42^{a b}$ & $2.4^{\mathrm{ab}}$ & $1.5^{\mathrm{ab}}$ & $14.9^{a b}$ & $427^{\mathrm{a}}$ \\
\hline C40 & 7.8 & $0.5^{\mathrm{a}}$ & $2.7^{\mathrm{a}}$ & $1.7^{\mathrm{a}}$ & $18.5^{\mathrm{a}}$ & $451.4^{\mathrm{a}}$ \\
\hline F-ANOVA & n.s. & $* *$ & $*$ & $*$ & $*$ & $* *$ \\
\hline CV (\%) & 1.2 & 15.3 & 9.2 & 5.1 & 20.0 & 3.8 \\
\hline \multicolumn{7}{|c|}{ Depth $21-40 \mathrm{~cm}$} \\
\hline $\mathrm{C}$ & 7.9 & $0.31^{b}$ & $1.9^{\mathrm{b}}$ & $1.1^{\mathrm{b}}$ & $10.1^{\mathrm{c}}$ & $389^{c}$ \\
\hline MF & 7.9 & $0.35^{\mathrm{b}}$ & $2^{b}$ & $1.3^{b}$ & $11.5^{\mathrm{c}}$ & $374^{\mathrm{bc}}$ \\
\hline $\mathrm{C} 20$ & 7.8 & $0.51^{\mathrm{a}}$ & $2.2^{\mathrm{b}}$ & $1.4^{\mathrm{ab}}$ & $14.2^{\mathrm{b}}$ & $417.9^{\mathrm{ab}}$ \\
\hline C40 & 7.8 & $0.58^{\mathrm{a}}$ & $3.3^{\mathrm{a}}$ & $1.6^{\mathrm{a}} 16.6^{\mathrm{a}}$ & $450.6^{\mathrm{a}}$ & \\
\hline F-ANOVA & n.s. & $* *$ & $*$ & $*$ & $* *$ & $*$ \\
\hline CV (\%) & 0.8 & 16.6 & 22.9 & 10.5 & 9.3 & 8.1 \\
\hline
\end{tabular}


especially with favourable climatic condition (abundant rainfall during spring and early summer) as occurred in the third year experiment.

Concerning soil fertility, application of compost increased organic matter and mineral elements content like $\mathrm{N}$, available $\mathrm{P}$ and $\mathrm{K}$ in the root zone of both rotations. The electric conductivity though increased of $58 \%$ in $\mathrm{C} 40$ and of $38 \%$ in $\mathrm{C} 20$ with regard to MF treatment, did not affect negatively crops yield, including those susceptible to salinity such as pepper.

\section{References}

Agritrasfer-In-Sud Campania - CdP Orticoltura, 2012. Elementi di conoscenza del compostaggio e dei compost e loro impiego in orticoltura. Available from: http://www.sito.regione.campania.it/agricoltura/pubblicazioni/pdf/conoscenza_compost.pdf

Cappelli S, Aureli L, 1998. L'utilizzo del compost in agricoltura: il recupero delle biomasse organiche e l'impiego su suolo agricolo. Agenzia Regionale per i Servizi di Sviluppo Agricolo, Avezzano $(A Q)$, Italy.

Casado-Vela J, Sellés S, Díaz-Crespo C, Navarro-Pedre o J, MataixBeneyto J, Gómez I, 2007. Effect of composted sewage sludge application to soil on sweet pepper crop (Capsicum annuum var. annuum) grown under two exploitation regimes. Waste Manage. 27:1509-18.

ECCP, 2001. European climate change programme report. Available from: http://ec.europa.eu/clima/policies/eccp/index_en.htm

European Commission, 2008. Directive 2008/98/EC of the European Parliament and of the Council of 19 November 2008 on waste and repealing certain Directives. In: Official Journal L 312/3, 22/11/2008. Available from: http://eur-lex.europa.eu/LexUriServ/Lex UriServ.do?uri=0J:L:2008:312:0003:0030:en:PDF
European Commission, 2011. Report from the Commission to the European Parliament, the Council, the European Economic and Social Committee and the Committee of the Regions on the thematic strategy on the prevention and recycling of waste SEC(2011) 70 final $*$ COM/2011/0013 final *. Available from: http://eurlex.europa.eu/legal-content/EN/TXT/?uri=CELEX:52011DC0013

Eghball B, Ginting D, Gilley JE, 2004. Residual effects of manure and compost application on corn production and soil properties. Agron. J. 96:442-7.

FA0-UNESC0, 1963. Ecological study of the Mediterranean zone. Bioclimatic map of the Mediterranean zone, explanatory notes. NS.162/III. 22/A, Paris, France.

Fecondo G, Guastadisegni G, D’Ercole M, Del Bianco M, Buda PA, 2008. Utilizzo di compost di qualità su colture arboree per il miglioramento della fertilità del terreno. Ital. J. Agron. 1:31-6.

Italian Regulation, 1982. Decreto del Presidente della Repubblica 10 settembre 1982, n. 915. Attuazione delle direttive (CEE) n. 75/442 relativa ai rifiuti, n. 76/403 relativa allo smaltimento dei policlorodifenili e dei policlorotrifenili e n. 78/319 relativa ai rifiuti tossici e nocivi. In: G. U. n. 343, 15/12/1982. Available from: http://www. sicet.it/pages/urbanistica/leggi_urb/DPR_915-82.htm

Italian Regulation, 2006a. Decreto Legislativo 3 aprile 2006, n. 152. Norme in materia ambientale. In: G. U. n. 88, 14/04/2006 - Suppl. Ord. n. 96. Available from: http://www.gazzettaufficiale.it/eli/ id/2006/04/14/006G0171/sg

Italian Regulation, 2006b. Decreto Legislativo 29 aprile 2006, n. 217. Revisione della disciplina in materia di fertilizzanti. In: G. U. n. 141, 20/06/2006 - Suppl. Ord. n. 152. Available from: http://www. gazzettaufficiale.it/atto/serie_generale/caricaArticoloDefault/originario?atto.dataPubblicazioneGazzetta=2007-03-16\&atto.codice Redazionale $=07 \mathrm{~A} 02321 \&$ atto.tipoProvvedimento $=$ DECRET0 